\title{
The Effect of Lipoteichoic Acid from Lactobacillus plantarum on Dental Pulp Inflammation
}

\author{
Meircurius Dwi Condro Surboyo ${ }^{5, \odot}$ \\ ${ }^{1}$ Department of Conservative Dentistry, Faculty of Dental Medicine, \\ Universitas Airlangga, Airlangga, Surabaya, Indonesia \\ 2Department of Oral Pathology and Maxillofacial, Faculty of Dental \\ Medicine, Universitas Airlangga, Airlangga, Surabaya, Indonesia \\ ${ }^{3}$ Department of Conservative Dentistry, Faculty of Dental Medicine, \\ Universitas Airlangga, Airlangga, Surabaya, Indonesia \\ ${ }^{4}$ Bachelor of Dental Science, Faculty of Dental Medicine, Universitas \\ Airlangga, Airlangga, Surabaya, Indonesia \\ ${ }^{5}$ Department of Oral Medicine, Faculty of Dental Medicine, \\ Universitas Airlangga, Airlangga, Surabaya, Indonesia
}

Nirawati Pribadi ${ }^{1}$ Retno Pudji Rahayu ${ }^{2}$ Kun Ismiyatin ${ }^{3}$ Cindy Ramadhan Putri ${ }^{4}$
Address for correspondence Nirawati Pribadi, MKes, SpKG(K), Department of Conservative Dentistry, Faculty of Dental MedicineUniversitas Airlangga, Jln. Prof. Dr. Moestopo 47, Surabaya 60132, Indonesia (e-mail: nirawati-p@fkg.unair.ac.id).

Eur J Dent 2021;15:682-686.

\author{
Abstract \\ Keywords \\ - dental pulp \\ - pulp inflammation \\ - lactobacillus \\ plantarum \\ - lipoteichoic acid \\ - neutrophils
}

Objective Lactobacillus plantarum, a bacterium located in deep caries, has a virulence factor in the form of lipoteichoic acid (LTA), which is found in the bacterial cell wall. LTA is able to trigger a neutrophils response in the dental pulp inflammation process within the first 6 to 24 hours. The quantity of bacteria is one factor influencing the increase in number of neutrophils in addition to the quality of the bacteria. This study seeks to analyze the effect of lipoteichoic acid of Lactobacillus plantarum (LTA-LP) in the dental pulp inflammation by observing the number of neutrophil cells in a histopathological view.

Materials and Methods The LTA was isolated from L. plantarum. The left upper molar of Rattus novergicus was mechanically perforated under anesthesia to induce dental pulp inflammation. The perforated tooth was then induced by 10 and $15 \mu \mathrm{g} / \mathrm{mL}$ of LTA-Lp and then restored by a temporary filling. The perforated tooth in the control group was only restored by a temporary filling. After 24,48 , and 72 hours, the tooth was extracted and then stained with hematoxylins and eosin to observe the neutrophils in the dental pulp via a light microscope.

Result The number of neutrophils in the dental pulp after induction by $15 \mu \mathrm{g} / \mathrm{mL}$ of LTA-Lp is higher than $10 \mu \mathrm{g} / \mathrm{mL}$ of LTA-Lp and both controls. There were significant differences in the number of neutrophils in the dental pulp, in each group on 24,48 , and 72 hours after LTA-Lp inducing $(p<0.05)$.

Conclusion The LTA-Lp dose of of 10 and $15 \mu \mathrm{g} / \mathrm{mL}$ affected the dental pulp inflammation by affecting the number of neutrophils. published online

August 20, 2021
DOI https://doi.org/

$10.1055 / \mathrm{s}-0041-1728238$

ISSN $1305-7456$ (c) 2021. European Journal of Dentistry.

This is an open access article published by Thieme under the terms of the Creative Commons Attribution-NonDerivative-NonCommercial-License, permitting copying and reproduction so long as the original work is given appropriate credit. Contents may not be used for commercial purposes, or adapted, remixed, transformed or built upon. (https://creativecommons.org/licenses/by-nc-nd/4.0/).

Thieme Medical and Scientific Publishers Pvt. Ltd. A-12, 2nd Floor, Sector 2, Noida-201301 UP, India 


\section{Introduction}

Dental pulp inflammation is the main response in teeth due to such injuries as trauma, chemicals, and microorganisms. ${ }^{1}$ Caries are caused by bacteria and aciduric toxic products that can cause the demineralization of enamel. ${ }^{2}$ Lactobacillus plantarum, a bacterium mostly found in deep caries and involves dentin, ${ }^{3}$ has lipoteichoic acid (LTA) and plays a role as a virulence factor. The lipoteichoic acid of Lactobacillus plantarum (LTA-Lp) has a trihexosyl-diacyl glycolipid structure; when it hits the pulp, it is received by odontoblasts, thus activating the dental pulp inflammation through Toll-like receptor 2 (TLR2) by activating the proinflammatory cytokines production. ${ }^{4}$

The first response to the inflammation is neutrophils recruitment at the site of inflammation. The neutrophil accumulation during the inflammatory process aims to eliminate the cause, as well as necrotic cells and tissues, so the process of wound healing and tissue repair may occur. ${ }^{5}$ During the first 6 to 24 hours, neutrophils dominate the inflammatory infiltrate, replaced by macrophages in the next 24 to 48 hours. ${ }^{6}$ In rabbits, researchers have different opinions concerning the neutrophil life cycle over a period of 3 to 5 days. $^{?}$

L. plantarumis gram-positive and facultative anaerobic bacteria have the ability to survive at a low $\mathrm{pH}^{8}{ }^{8}$ The virulence of bacteria is influenced by the LTA quality as well as quantity in terms of causing damage to the dental pulp. ${ }^{1}$ Other studies have postulated that using Streptococcus aureus lipoteichoic acid at a concentration of $10 \mu \mathrm{g} / \mathrm{mL}$ may effectively induce neutrophil activation; although at higher concentrations $(20-100 \mu \mathrm{g} / \mathrm{mL})$, it did not show a continued increase in neutrophil activation. ${ }^{9}$ But no studies have shown that effect of LTA-Lp can cause acute pulp inflammation. Hence, it is necessary to analyze the effect of LTA-Lp of 10 and $15 \mu \mathrm{g} / \mathrm{mL}$ on dental pulp inflammation in Rattus novergicus by observing the number of neutrophil cells after 24,48 , and 72 hours.

\section{Materials and Methods}

\section{Animals}

The protocol of this study was approved by the Ethical Committee Faculty of Dental Medicine, Universitas Airlangga, with registration number783/HRECC.FODM/XII/2019. This type of research is a laboratory experiment in vivo using white male $R$. novergicus with the following criteria:

- The sex is male

- The age of 24 to 32 weeks

- Weight 270 to $350 \mathrm{~g}$

- The maxillary left first molar was fully developed and in good physical condition (no caries)

This study included $48 R$. novergicus specimens with the number of each group at each observation time consisting of four rats. This study was divided into four groups with three observation times (24, 48, and 72 hours), namely:

- Group A (negative control) animal without treatment

- Group B (positive control), the left upper molar was mechanically perforated and then filled with a temporary filling
- Group C, the left upper molar was mechanically perforated, followed by LTA-Lp of $10 \mu \mathrm{g} / \mathrm{mL}$ induction and then filled with a temporary filling

- Group D, the left upper molar was mechanically perforated, followed by LTA-Lp of $15 \mu \mathrm{g} / \mathrm{mL}$ induction and then filled with a temporary filling

\section{Extraction and Purification of Lipoteichoic Acid of Lactobacillus plantarum}

L. plantarum were cultured in a Mueller-Hinton broth (Biokar diagnostic, France) at $37^{\circ} \mathrm{C}$ and centrifuged at $150 \mathrm{rpm}$ for 24 hours. After reaching the end log phase, the $400 \mathrm{~mL}$ culture was then centrifuged at $4,000 \mathrm{rpm}$ for 15 minutes at $4^{\circ} \mathrm{C}$. Cells were then washed three times with $0.1 \mathrm{M}$ tris-HCL buffer, pH level of 8 (Furobro, France) and then resuspended at $20 \mathrm{~mL}, 0.1 \mathrm{M}$ acetate buffer, pH level of 4.7 (Fisher scientific, United Kingdom). Cells were mixed with N-Butanol and incubated for 30 minutes at $37^{\circ} \mathrm{C}$ under agitation at $300 \mathrm{rpm}$.

The extraction process started with cells being centrifuged at $13,000 \mathrm{rpm}$ for 15 minutes at $4^{\circ} \mathrm{C}$. The aqueous phase was collected, resuspended again in $20 \mathrm{~mL}$ of $0.1 \mathrm{M}$ ammonium acetate buffer, $\mathrm{pH}$ level of 4.7 , and then sonicated three times; each for 1 minute to break the cell walls. After sonication, the cell suspension was mixed with $\mathrm{N}$-Butanol for 30 minutes at $37^{\circ} \mathrm{C}$ and centrifuged at $300 \mathrm{rpm}$ to produce crude lipoteichoic acid. The fractions in each extraction were placed at pH 8.5 with $\mathrm{NH} 3$, incubated overnight at $37^{\circ} \mathrm{C}$, and monitored by gas chromatography mass spectrometry. The purification of lipoteichoic acid was achieved by adding a $0.1 \mathrm{M}$ ammonium acetate buffer with $15 \% \mathrm{~N}-$ Propanol $(\mathrm{pH}=4.7)$ and then filtered.

\section{Lipoteichoic Acid of Lactobacillus plantarum Dosages}

The $0.4779 \mathrm{mg}$ LTA-Lp were diluted with $1 \mathrm{~mL}$ of distilled water and shaken until homogeneous using a vibrator (Vortex). The LTA-Lp $10 \mu \mathrm{g} / \mathrm{mL}$ obtained from $20 \mu \mathrm{L}$ of LTA-Lp solution was put into Eppendorf and then $780 \mathrm{~mL}$ of distilled water were added and shaken until homogeneous. The LTA-Lp of $15 \mu \mathrm{g} / \mathrm{mL}$ obtained from $30 \mu \mathrm{L}$ of LTA-Lp was put into Eppendorf; thereafter, $770 \mathrm{~mL}$ of distilled water were added and shaken until homogeneous. ${ }^{10}$

\section{Lipoteichoic Acid of Lactobacillus plantarum Induction Procedure}

Each $R$. novergicus was anesthetized with Ketamine HCL (Ketalar, Warner Lambert, Ireland, $70 \mathrm{mg} / \mathrm{kg}$ body weight) and Xylazine base (Xyla, PT Tekad Mandiri Citra, $7 \mathrm{mg} / \mathrm{kg}$ body weight) dissolved in phosphate buffer saline according to the group of observation hours.

The dental pulp inflammation was created in the left upper molar by opening the pulp chamber using a round bur and high-speed rotary instrument. ${ }^{11}$ LTA-Lp was administered at a dose of 10 and $15 \mu \mathrm{g} / \mathrm{mL}$ as much as $1 \mu \mathrm{L}$ of micropipette using a sterile paper point on the surface of the perforated pulp chamber; this was repeated five times. The cavity was then cleaned with a cotton pellet, filled with a temporary filling (Cention-N, Ivoclar Vivadent, Liechtenstein), and then irradiated with a light cure technique for 40 seconds. ${ }^{10,12}$ 
After 24, 28, and 72 hours of this procedure, the left upper molar was extracted under anesthesia.

\section{Analysis of the Number of Neutrophils on Dental Pulp} The histological preparations were made by hematoxylins and eosin (HE) staining the tooth specimen, and the number of neutrophils in each group was analyzed on dental pulp. The histopathology of pulp tissue was observed via a Nikon E100 light microscope starting at $\times 400$ magnification of 10 fields of view to see the type of histological section of dental pulp in the area of perforation.

\section{Data Analysis}

The results of the study were calculated as mean and standard deviation. The normality test used the Kolmogorov-Smirnov test, followed by the homogeneity test using the Levene test. The parametric test was performed by using a one-way ANOVA test and a post hoc test with $p<0.05$ considered as a significant difference.

\section{Results}

\section{The Number of Neutrophils on Dental Pulp}

The number of neutrophils was analyzed in dental pulp in the area of perforation (black arrow; - Fig. 1). The number of neutrophils in the LTA-Lp $15 \mu \mathrm{g} / \mathrm{mL}$ (Group D) is higher compared LTA-Lp of $10 \mu \mathrm{g} / \mathrm{mL}$ (Group C), control positive (Group B), and control negative (Group A).

The observation after 24,48 , and 72 hours induced by LTA-Lp, and the number of neutrophils in the LTA-Lp 15 of $\mu \mathrm{g} / \mathrm{mL}$ (Group D) is higher compared with LTA-Lp $10 \mu \mathrm{g} / \mathrm{mL}$ (Group $C$ ), control positive (Group $B$ ), and control negative (Group A; $p=0.003 ; p=0.005 ; p=0.003$; respectively;

\section{- Table 1).}

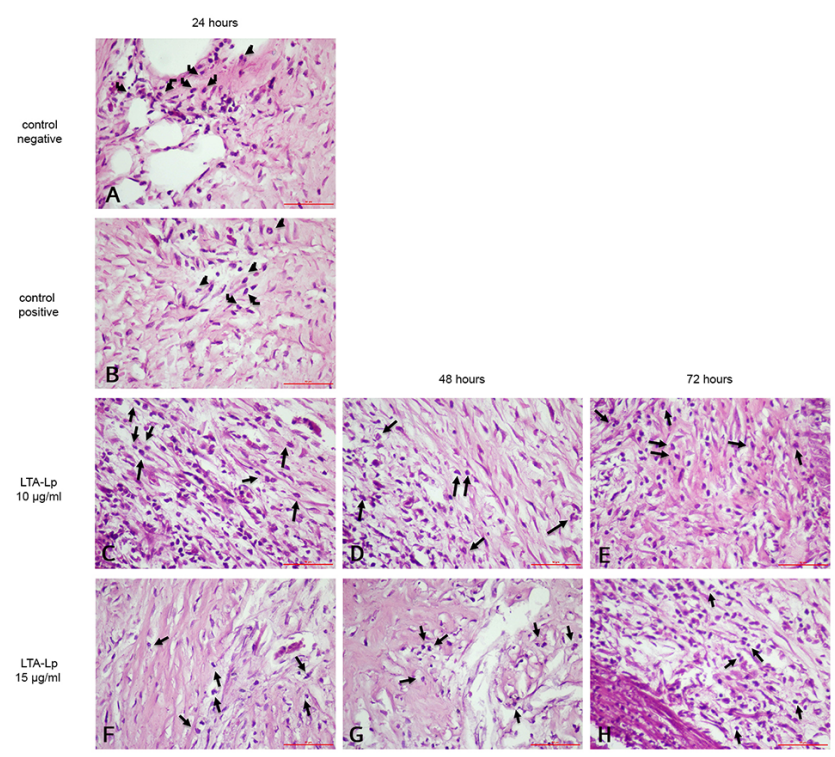

Fig. 1 The number of neutrophils (black arrows) in the dental pulp on the perforated area. The analyses used hematoxylin and eosin staining with light microscope on $\times 400$ magnification.

\section{Discussion}

L. plantarumis the second-most common bacteria after Lactobacillus acidophilus, which dominates in the border area of the dentin and pulp. ${ }^{13}$ Dental pulp inflammation in this study occurred due to LTA-Lp. The LTA is the L. plantarum cell wall component, which is able to attach to host cells causing an inflammatory response. ${ }^{4}$ When exposed to LTA-Lp or mechanical lesions (dental pulp perforation), the number of neutrophil cells will increase. The number of neutrophils in the homeostatic condition and no inflammatory condition is found more than $50 \%$ of all leukocytes in the bloodstream. The average neutrophil produced in the bone marrow reaches $10^{11}$ cells/day before finally being released into the bloodstream and circulating in the blood for 6 to 12 hours; thereafter, the neutrophils will go to all tissues. ${ }^{14,15}$

In the dental pulp induced by LTA-Lp 10 and $15 \mu \mathrm{g} / \mathrm{mL}$, the number of neutrophils was higher than the mechanical perforation. This was because LTA-Lp has toxic properties, is able to stimulate inflammatory responses, and can survive in an acidic environment up to a $\mathrm{pH}$ of 2.2. ${ }^{16,17}$ The inflammatory response begins with a vascular response, in which the blood vessels undergo a vasoconstriction, decreasing the blood flow; thereafter, the blood vessels undergo a vasodilation phase, an increase in permeability, and an increase capillary blood flow, causing a migration of neutrophils to the interstitial tissue through the opening of the endothelial interspace of the blood vessels. ${ }^{18}$ Neutrophils act as the first defense of the innate immunity to eliminate lesions. Neutrophil cells are in the blood vessels and, as the body's first form of defense against bacterial injury, will increase if there is a bacterial injury. In most cases of acute inflammation, neutrophil cells predominate in the first 6 to 24 hours and will be replaced by macrophages in the next 24 to 48 hours. ${ }^{19}$

This study also found that the number of neutrophils in the LTA-Lp of $15 \mu \mathrm{g} / \mathrm{mL}$ is higher than in LTA-Lp of $10 \mu \mathrm{g} / \mathrm{mL}$. This is influenced by the virulence of L. plantarum, including the quantity of bacteria (dose or concentration). ${ }^{1}$ Moreover, LTA from gram-positive bacteria such as L. plantarum, as a virulence factor with the main components of the cell wall containing phosphate and glycolipids, can trigger the neutrophil and macrophage recruitment. ${ }^{20}$ Odontoblasts are known to play an important role in activating innate immunity and adaptive immune response. ${ }^{21}$ LTA-Lp will be specifically recognized by TLR2 on the surface of odontoblast cells through the trihexosyl-diacyl structure in the LTA. ${ }^{4}$ When there is a lesion, neutrophils will accumulate in the tissue exposed to the injury to carry out its phagocytosis function and mediate the presentation of LTA through TLR2 by macrophages. ${ }^{22}$ The TLR2 activation will mobilize MyD88 to initiate mitogen-activated protein kinase and nuclear factor kappa $\beta$ activation, thus inducing the release of proinflammatory cytokines such as interleukin 8 (IL-8), IL-1, and tumor necrosis factor $\alpha^{20,23-25}$ The release of IL- 8 has a role in inducing the release and activation of neutrophils in the inflammation of dental pulp; this event will be repeated until the neutrophils complete their task before being replaced by macrophages. ${ }^{26}$ 
Table 1 The mean and standard deviation of the number of neutrophil cells in each group

\begin{tabular}{|c|c|c|c|c|c|c|}
\hline & $24 \mathrm{~h}$ & $p$-Value & $48 \mathrm{~h}$ & $p$-Value & $72 \mathrm{~h}$ & $p$-Value \\
\hline Group A (control -) & $1.50 \pm 0.57$ & \multirow[t]{4}{*}{$0.003^{\mathrm{a}}$} & $1.50 \pm 0.57$ & \multirow[t]{4}{*}{$0.005^{\mathrm{a}}$} & $1.50 \pm 0.57$ & \multirow[t]{4}{*}{$0.003^{a}$} \\
\hline Group B (control +) & $2.75 \pm 0.50$ & & $7.75 \pm 0.50$ & & $5.00 \pm 0.82$ & \\
\hline Group C (LTA-Lp 10 g/mL) & $4.75 \pm 0.95$ & & $8.50 \pm 1.29$ & & $7.75 \pm 0.50$ & \\
\hline Group D (LTA-Lp 15 g/mL) & $9.25 \pm 1.25$ & & $10.75 \pm 0.95$ & & $9.75 \pm 0.95$ & \\
\hline
\end{tabular}

Abbreviation: LTA-Lp, lipoteichoic acid of Lactobacillus plantarum.

aSignificant different with compared each group $(p<0.05)$.

Note: $p$-value is significant value with post hoc test.

The LTA-Lp dose of 10 and $15 \mu \mathrm{g} / \mathrm{mL}$ affected the dental pulp inflammation by increasing the number of neutrophils after 24, 48, and 72 hours. The results of this study are expected to provide knowledge about the virulence of L. plantarum. Consequently, in the treatment of dental disorders such as deep caries, a material that can inhibit the development of the L. plantarum can be given.

The limitation of this study is analyzed the number of neutrophils after LTA-Lp induction, so that it cannot see the overall response to inflammation and the mechanisms involved. The future study requires confirmation of the overall cellular response and the mechanism involved of LTA-Lp in the dental pulp inflammation.

\section{Conclusion}

The LTA-Lp dose of 10 and $15 \mu \mathrm{g} / \mathrm{mL}$ affected the dental pulp inflammation by increasing the number of neutrophils after 24, 48, and 72 hours.

\section{Funding}

This study is supported by the Faculty of Dental Medicine Universitas Airlangga in the schema Penelitian Unggulan Fakultas (PUF) 2019 with registration number: 2136/UN.3.1.2/LT/2019.

\section{Conflict of Interest}

None declared.

\section{References}

1 Ashley NT, Weil ZM, Nelson RJ. Inflammation: mechanisms, costs, and natural variation. Vol. 43. Annu Rev Ecol Evol Syst 2012;385-406

2 Kiranmayi G, Anumala L, Kirubakaran R. Estimation of the prevalence of pulpitis in the tertiary care hospital in nellore district: a cross sectional study. IOSR J Dent Med Sci 2019; 18(8):63-66

3 Callaway A, Kostrzewa M, Willershausen B, et al. Identification of Lactobacilli from deep carious lesions by means of species-specific PCR and MALDI-TOF mass spectrometry. Clin Lab 2013;59(11-12):1373-1379

4 Jang KS, Baik JE, Han SH, Chung DK, Kim BG. Multi-spectrometric analyses of lipoteichoic acids isolated from Lactobacillus plantarum. Biochem Biophys Res Commun 2011; 407(4):823-830

5 Chen L, Deng H, Cui H, et al. Inflammatory responses and inflammation-associated diseases in organs. Oncotarget 2017; 9(6):7204-7218
6 Cilmiaty R, Pribadi N, Rukmo M, Surboyo MDC. The NFKB expression on apical dental granuloma: an immunohistochemistry analysis. Clin Cosmet Investig Dent 2020;12:313-318

7 Hidalgo A, Chilvers ER, Summers C, Koenderman L. The neutrophil life cycle. Trends Immunol 2019;40(7):584-597

8 Yadav K, Prakash S. Dental caries: a microbiological approach. J Clin Infect Dis Pract 2017;2(1);1000118 doi:10.4172/2476-213X.1000118

9 Hattar K, Grandel U, Moeller A, et al. Lipoteichoic acid (LTA) from Staphylococcus aureus stimulates human neutrophil cytokine release by a CD14-dependent, Toll-like-receptorindependent mechanism: autocrine role of tumor necrosis factor- $[\alpha]$ in mediating LTA-induced interleukin-8 generation. Crit Care Med 2006;34(3):835-841

10 Renard E, Gaudin A, Bienvenu G, et al. Immune cells and molecular networks in experimentally induced pulpitis. J Dent Res 2016;95(2):196-205

11 Pribadi N, Budiarti D, Kurniawan HJ, Widjiastuti I. The NF-kB and collagen type 1 expression in dental pulp after treated calcium hydroxide combined with propolis. Eur J Dent 2021;15(1):122126 doi:10.1055/s-0040-1716319

12 Takimoto K, Kawashima N, Suzuki N, et al. Down-regulation of inflammatory mediator synthesis and infiltration of inflammatory cells by MMP-3 in experimentally induced rat pulpitis. J Endod 2014;40(9):1404-1409

13 Kim KW, Kang SS, Woo SJ, et al. Lipoteichoic acid of probiotic Lactobacillus plantarum attenuates poly I: C-induced IL-8 production in porcine intestinal epithelial cellss. Front Microbiol 2017;8:1827. Doi:10.3389/fmicb.2017.01827

14 Adrover JM, Nicolás-Ávila JA, Hidalgo A. Aging: a temporal dimension for neutrophils. Trends Immunol 2016;37(5): 334-345

15 Summers C, Rankin SM, Condliffe AM, Singh N, Peters AM, Chilvers ER. Neutrophil kinetics in health and disease. Trends Immunol 2010;31(8):318-324

16 Singh Ahirwar S, Gupta MK, Snehi SK, Dadasaheb Kalmegh S. Dental caries and lactobacillus: role and ecology in the oral cavity. Int J Pharm Sci Res 2019;10(11):4818-4829

17 Caufield PW, Schön CN, Saraithong P, Li Y, Argimón S. Oral lactobacilli and dental caries: a model for niche adaptation in humans. J Dent Res 2015;94, 9(Suppl):110S-118S

18 Sansbury BE, Spite M. Resolution of acute inflammation and the role of resolvins in immunity, thrombosis, and vascular biology. Circ Res 2016;119(1):113-130

19 Hirayama D, Iida T, Nakase H. The phagocytic function of macrophage-enforcing innate immunity and tissue homeostasis. Int J Mol Sci 2017;19(1):E92

20 Kang SS, Sim JR, Yun CH, Han SH. Lipoteichoic acids as a major virulence factor causing inflammatory responses via Toll-like receptor 2. Arch Pharm Res 2016;39(11):1519-1529

21 Farges JC, Alliot-Licht B, Renard E, et al. Dental pulp defence and repair mechanisms in dental caries. Mediators Inflamm 2015;2015:230251. Doi:10.1155/2015/230251 
22 Plüddemann A, Mukhopadhyay S, Gordon S. Innate immunity to intracellular pathogens: macrophage receptors and responses to microbial entry. Immunol Rev 2011;240(1):11-24

23 Dimitrovski D, Cencic A, Winkelhausen E, Langerholc T. Lactobacillus plantarum extracellular metabolites: in vitro assessment of probiotic effects on normal and cancerogenic human cells. Int Dairy J 2014;39(2):293-300

24 Surboyo MDC, Mahdani FY, Ernawati DS, Sarasati A, Rezkita F. The macrophage responses during diabetic oral ulcer healing by liquid coconut shell smoke: an immunohistochemical analysis. Eur J Dent 2020;14(3):410-414

25 Surboyo MDC, Arundina I, Rahayu RP, Mansur D, Bramantoro T. Potential of distilled liquid smoke derived from coconut (cocos nucifera L) shell for traumatic ulcer healing in diabetic rats. Eur J Dent 2019;13(2):271-279

26 Farges JC, Carrouel F, Keller JF, et al. Cytokine production by human odontoblast-like cells upon Toll-like receptor-2 engagement. Immunobiology 2011;216(4):513-517 